\author{
Marquette University \\ e-Publications@Marquette
}

1996

\title{
Characterization of the Structural and Electronic Properties of Spin-Coupled Dinuclear Copper(II) Centers by Proton NMR Spectroscopy
}

Julie M. Brink

Utah State University

Rachel A. Rose

Utah State University

Richard C. Holz

Marquette University, richard.holz@marquette.edu

Follow this and additional works at: https://epublications.marquette.edu/chem_fac

Part of the Chemistry Commons

\section{Recommended Citation}

Brink, Julie M.; Rose, Rachel A.; and Holz, Richard C., "Characterization of the Structural and Electronic Properties of Spin-Coupled Dinuclear Copper(II) Centers by Proton NMR Spectroscopy" (1996). Chemistry Faculty Research and Publications. 300.

https://epublications.marquette.edu/chem_fac/300 
Marquette University

e-Publications@Marquette

\section{Chemistry Faculty Research and Publications/College of Arts and Sciences}

This paper is NOT THE PUBLISHED VERSION; but the author's final, peer-reviewed manuscript. The published version may be accessed by following the link in the citation below.

Inorganic Chemistry, Vol. 35, No. 10 (May 8, 1996): 2878-2885. DOI. This article is (C) American Chemical Society Publications and permission has been granted for this version to appear in $\underline{\mathrm{e}}-$ Publications@Marquette. American Chemical Society Publications does not grant permission for this article to be further copied/distributed or hosted elsewhere without the express permission from American Chemical Society Publications.

\section{Characterization of the Structural and Electronic Properties of Spin-Coupled Dinuclear Copper(II) Centers by Proton NMR Spectroscopy}

Julie M. Brink

Department of Chemistry and Biochemistry, Utah State University, Logan, Utah Rachel A. Rose

Department of Chemistry and Biochemistry, Utah State University, Logan, Utah Richard C. Holz

Department of Chemistry and Biochemistry, Utah State University, Logan, Utah

SUBJECTS:

Crystallography, X-rays, Pyridines, Ions, 


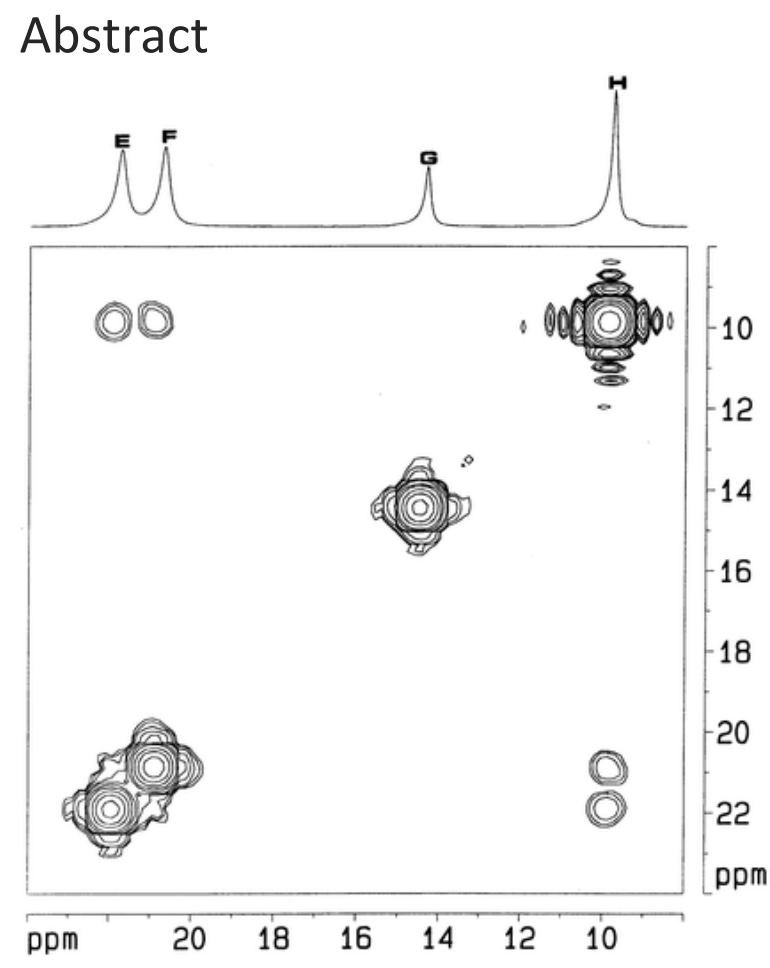

The ${ }^{1} \mathrm{H}$ NMR spectra of a series of well-characterized $\mu$-phenoxo and $\mu$-alkoxo spin-coupled dicopper(II) complexes have been investigated. The complexes studied were $\left[\mathrm{Cu}_{2}(\mathrm{BPMP})(\mathrm{OH})\right]^{2+}(\mathbf{1})(\mathrm{BPMP}=2,6-\mathrm{bis}[[\mathrm{bis}(2-$ pyridylmethyl)amino]methyl]-4-methylphenol), $\left[\mathrm{Cu}_{2}\left(\mathrm{CH}_{3} \mathrm{HXTA}\right)(\mathrm{OH})\right]^{2-}(2)\left(\mathrm{CH}_{3} \mathrm{HXTA}=\mathrm{N}, \mathrm{N}^{-}\right.$-(2-hydroxy-5-methyl1,3-xylylene)bis( $N$-carboxymethylglycine), $\left[\mathrm{Cu}_{2}(m-\mathrm{XYL})(\mathrm{OH})\right]^{2+}(3)(m-\mathrm{XYL}=2,6$-bis $[[\mathrm{bis}(2-$

pyridylethyl)amino]methyl]phenol), and $\left[\mathrm{Cu}_{2}(\mathrm{TBHP})(\mathrm{OAC})\right]^{2+}(4)\left(\mathrm{TBHP}=\mathrm{N}, \mathrm{N}^{\prime} \mathrm{N}^{\prime}, \mathrm{N}^{\prime}\right.$-tetrakis $[(2-$

benzimidazolyl)methyl]-2-hydroxy-1,3-diaminopropane). The magnetic interactions of these complexes range from strongly antiferromagnetically to weakly ferromagnetically coupled. Both one- and two-dimensional (COSY) ${ }^{1} \mathrm{H}$ NMR methods were used to facilitate the assignment of the hyperfine shifted ${ }^{1} \mathrm{H}$ NMR signals of each complex. COSY experiments provide clear cross signals for resonances $<200 \mathrm{~Hz}$ wide. These data have facilitated the assignment of the hyperfine shifted ${ }^{1} \mathrm{H}$ NMR signals and have verified that the solid state structures exist in solution for each system studied. Assuming a paramagnetic dipolar relaxation mechanism, the crystallographically determined $\mathrm{Cu}-\mathrm{H}$ distance $(r)$ is proportional to $T_{1}{ }^{1 / 6}$. All calculated $\mathrm{Cu}-\mathrm{H}$ distances for 1-4 are within $\mathrm{ca}$. $20 \%$ of the $\mathrm{Cu}-\mathrm{H}$ distances derived from X-ray crystallography. These data indicate that a paramagnetic dipolar relaxation mechanism is the dominant proton relaxation pathway for spin-coupled dicopper(II) centers. Our results indicate that ${ }^{1} \mathrm{H}$ NMR spectroscopy is an excellent tool with which to probe the solution structures of spin-coupled dicopper(II) centers in model complexes as well as biological systems.

\section{Synopsis}

One- and two-dimensional ${ }^{1} \mathrm{H}$ NMR spectra of both antiferromagnetically and ferromagnetically coupled $\mu$ phenoxo and $\mu$-alkoxo dicopper(II) complexes have been recorded. Two-dimensional COSY experiments provide clear cross signals for resonances $<200 \mathrm{~Hz}$ wide and establish spin-spin connectivities. These data have facilitated the assignment of hyperfine shifted ${ }^{1} \mathrm{H}$ NMR signals in dicopper(II) complexes and have verified that the solid state structures exist in solution for each system studied. In addition, relaxation data coupled with Xray crystallographic results indicate that a paramagnetic dipolar relaxation mechanism is the dominant proton relaxation pathway. 


\section{Introduction}

Proton NMR spectroscopy has been widely used to study the structural and electronic properties of spincoupled diiron, iron-sulfur cluster, and heterobimetallic systems such as those prepared from superoxide dismutase. ${ }^{1-51} \mathrm{H}$ NMR spectroscopy is an extremely sensitive tool for the study of these systems since only protons proximate to a paramagnetic center are affected, resulting in a fingerprint of the active site. In addition, a wealth of magnetic information on spin-coupled systems (e.g., 4Fe-4S clusters) has been obtained by measuring the temperature dependence of the isotropically shifted signals. ${ }^{3,5}$ These studies allow local spin magnetization to be characterized without interference from the bulk susceptibility. Despite these successes, ${ }^{1} \mathrm{H}$ NMR spectroscopy has been largely overlooked as a probe of the electronic properties of other spin-coupled transition metal ions (e.g., copper) in biological systems. The characterization of the structure and function of dicopper(II) centers in biological systems is a problem of outstanding importance since these enzymes play many varied roles in nature including dioxygen activation and reversible dioxygen binding. ${ }^{6-10}$ Therefore, a thorough understanding of the ${ }^{1} \mathrm{H}$ NMR spectra of simple biomimetic complexes must be developed before ${ }^{1} \mathrm{H}$ NMR spectroscopy can be established as a probe of the structural and magnetic properties of spin-coupled dinuclear $\mathrm{Cu}(\mathrm{II})$ centers in biological systems.

The synthesis and characterization of dinuclear $\mathrm{Cu}(\mathrm{II})$ complexes has received a great deal of attention because of the role of dicopper centers in biological processes. ${ }^{6,10-12} \mathrm{As}$ a result, these biomimetic dicopper(II) complexes have been extensively studied using several physical techniques such as electronic absorption spectroscopy, EPR, X-ray crystallography, and magnetic susceptibility. ${ }^{101} \mathrm{H}$ NMR spectroscopy has only recently emerged as a window into the structural and magnetic properties of dinuclear $\mathrm{Cu}(\mathrm{II})$ complexes. It has been proposed that relatively sharp hyperfine shifted ${ }^{1} \mathrm{H}$ NMR signals are observed due to the proximity of the ground and first excited states, which are separated by the magnitude of the exchange constant, $-2 J .{ }^{13,141} \mathrm{H}$ NMR spectra have been reported for antiferromagnetically and ferromagnetically coupled systems and both provide relatively sharp, hyperfine shifted ${ }^{1} \mathrm{H}$ NMR signals. ${ }^{13,15-23} \mathrm{However}$, the majority of the studies reported to date have relied on laborious synthetic methods such as substitution or deuteration to assign only a portion of the observed isotropically shifted signals. Therefore, ${ }^{1} \mathrm{H}$ NMR spectroscopy has been of little utility as a structural or magnetic probe of dicopper(II) centers.

Our laboratory recently communicated that two-dimensional (COSY) ${ }^{1} \mathrm{H}$ NMR techniques can be performed on dicopper(II) complexes facilitating the assignment of observed hyperfine shifted ${ }^{1} \mathrm{H}$ NMR resonances. ${ }^{20} \mathrm{We}$ report here one- and two-dimensional ${ }^{1} \mathrm{H}$ NMR studies on a series of magnetically diverse $\mu$-phenoxo and $\mu$ alkoxo dicopper(II) complexes (Figure 1). These complexes, $\left[\mathrm{Cu}_{2}(\mathrm{BPMP})(\mathrm{OH})\right]^{2+}(\mathbf{1}),\left[\mathrm{Cu}_{2}\left(\mathrm{CH}_{3} \mathrm{HXTA}\right)(\mathrm{OH})\right]^{2-}(\mathbf{2})$, $\left[\mathrm{Cu}_{2}(m-\mathrm{XYL})(\mathrm{OH})\right]^{2+}(3)$, and $\left[\mathrm{Cu}_{2}(\mathrm{TBHP})(\mathrm{OAc})\right]^{2+}(4)$, have been thoroughly characterized by X-ray crystallography as well as several spectroscopic methods. ${ }^{20,21,24-28}$ The spin-coupling interactions for these complexes, determined from SQUID susceptibility measurements, range from strongly antiferromagnetically to weakly ferromagnetically coupled. Clear COSY cross signals are observed between hyperfine shifted ${ }^{1} \mathrm{H}$ NMR resonances for both types of spin-coupled complexes. These data have facilitated the assignment of the hyperfine shifted ${ }^{1} \mathrm{H}$ NMR signals and have verified that the solid state structures exist in solution for each system studied. Combining signal assignment with $\mathrm{X}$-ray crystallographic results and $T_{1}$ information has allowed us to address the mechanism of relaxation for spin-coupled dicopper(II) centers. Our data indicate that ${ }^{1} \mathrm{H}$ NMR spectroscopy is an excellent tool with which to probe the structural and magnetic properties of dicopper(II) centers in both model complexes and biological systems. 


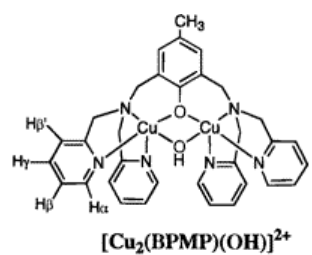

(1)

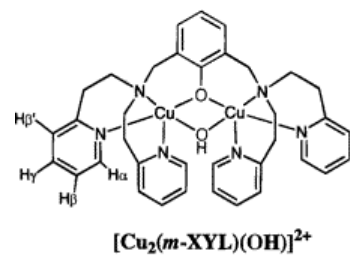

(3)

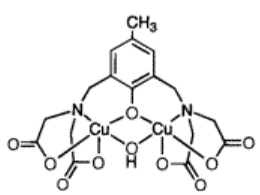

$\left[\mathrm{Cu}_{2}\left(\mathrm{CH}_{3} \mathrm{HXTA}\right)(\mathrm{OH})\right]^{2-}$

(2)

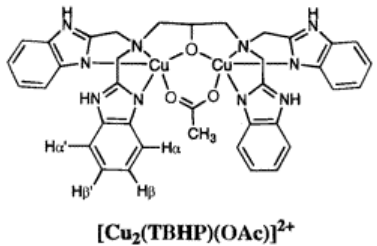

(4)

Figure 1 Schematic representations of $\left[\mathrm{Cu}_{2}(\mathrm{BPMP})(\mathrm{OH})\right]^{2+}(\mathbf{1}),\left[\mathrm{Cu}_{2}\left(\mathrm{CH}_{3} \mathrm{HXTA}\right)(\mathrm{OH})\right]^{2-}(\mathbf{2}),\left[\mathrm{Cu}_{2}(m-\mathrm{XYL})(\mathrm{OH})\right]^{2+}(\mathbf{3})$, and $\left[\mathrm{Cu}_{2}(\mathrm{TBHP})(\mathrm{OAc})\right]^{2+}(4)$.

\section{Experimental Methods}

\section{Synthetic Methods.}

All chemicals were purchased commercially and used as received unless otherwise stated. The dinucleating ligand 2,6-bis[[bis(2-pyridylmethyl)amino]methyl]-4-methylphenol (BPMP) was prepared according to the method of Suzuki et al. ${ }^{29,30}$ with revisions as reported by Borovik et al. ${ }^{31} N, N, N^{\prime}, N$ '-tetrakis[(2benzimidazolyl)methyl]-2-hydroxy-1,3-diaminopropane (TBHP) was obtained by condensing 1,2diaminobenzene with 1,3-diamino-2-hydroxypropane- $N, N, N^{\prime}, N$ '-tetraacetic acid according to the method of McKee et al. ${ }^{25}$ with minor revisions. $N, N^{\prime}-(2-H y d r o x y-5-m e t h y l-1,3-x y l y l e n e) b i s(N$-carboxymethylglycine) $\left(\mathrm{CH}_{3} \mathrm{HXTA}\right)$ was synthesized from $p$-cresol, iminodiacetic acid, and formaldehyde according to the method of Schwarzenbach et al. $^{32}$ with minor revisions as reported by Murch et al. ${ }^{33}$

$\left[\mathrm{Cu}_{2}(\mathrm{BPMP})(\mathrm{OH})\right]\left(\mathrm{ClO}_{4}\right)_{2}(\mathbf{1})$ was prepared by the method of Berands et al. ${ }^{34}$ To a stirred methanol solution (20 $\mathrm{mL}$ ) containing $(0.64 \mathrm{~g} ; 1.2 \mathrm{mmol}) \mathrm{HBPMP}, 1.2 \mathrm{~g}(2.4 \mathrm{mmol})$ of $\mathrm{Cu}\left(\mathrm{ClO}_{4}\right)_{2} \cdot 6 \mathrm{H}_{2} \mathrm{O}$ dissolved in $2 \mathrm{~mL}$ of methanol was added. Triethylamine (1 equiv) was added to the resulting brown solution, upon which the solution turned a deep green. After filtration, 1 was recrystallized by vapor diffusion with diethyl ether. The analytical purity of 1 was checked by elemental analysis (Atlantic Microlab, Inc.). Calculated for $\left[\mathrm{Cu}_{2}(\mathrm{BPMP})(\mathrm{OH})\right]\left(\mathrm{ClO}_{4}\right)_{2}(\mathbf{1})$ $\left(\mathrm{C}_{33} \mathrm{H}_{34} \mathrm{~N}_{6} \mathrm{O}_{10} \mathrm{Cl}_{2} \mathrm{Cu}_{2}\right):$ C, 45.42; $\mathrm{H}, 3.93 ; \mathrm{N}, 9.63$. Found: $\mathrm{C}, 45.52 ; \mathrm{H}, 3.98 ; \mathrm{N}, 9.57 . \mathrm{Na}_{2}\left[\mathrm{Cu}_{2}\left(\mathrm{CH}_{3} \mathrm{HXTA}\right)(\mathrm{OH})\right](2)$ was synthesized as previously described, and $\left[\mathrm{Cu}_{2}(m-\mathrm{XYL})(\mathrm{OH})\right]\left(\mathrm{PF}_{6}\right)_{2}(3)$ was provided as a kind gift by Dr. Kenneth Karlin.

$\left[\mathrm{Cu}_{2}(\mathrm{TBHP})(\mathrm{OAC})\right]\left(\mathrm{ClO}_{4}\right)_{2}(4)$ was prepared by the method of Mckee et al. ${ }^{25}$ with minor revisions as reported by Satcher and Balch. ${ }^{22}$ The electronic absorption spectrum of $\mathbf{4}$ in acetonitrile solution was identical to that reported by McKee et al. ${ }^{25}$ The analytical purity of 4 was determined by elemental analysis (Atlantic Microlab, Inc.). Calculated for $\left[\mathrm{Cu}_{2}(\mathrm{TBHP})(\mathrm{OAC})\right]\left(\mathrm{ClO}_{4}\right)_{2}\left(\mathrm{C}_{36} \mathrm{H}_{36} \mathrm{~N}_{10} \mathrm{O}_{11} \mathrm{Cl}_{2} \mathrm{Cu}_{2}\right): \mathrm{C}, 44.64 ; \mathrm{H}, 3.65 ; \mathrm{N}, 14.08$. Found: $\mathrm{C}, 44.37 ; \mathrm{H}$, 3.78; $\mathrm{N}, 13.94$. The benzoate derivative of $4\left[\mathrm{Cu}_{2}(\mathrm{TBHP})(\mathrm{OBz})\right]\left(\mathrm{ClO}_{4}\right)_{2}(5)$ was synthesized identically to that of 4. The electronic absorption spectrum of 5 in acetonitrile solution shows absorbance maxima at 795 and $1045 \mathrm{~nm}$. The analytical purity of 5 was determined by elemental analysis (Atlantic Microlab, Inc.). Calculated for $\left[\mathrm{Cu}_{2}(\mathrm{TBHP})(\mathrm{OBz})\right]\left(\mathrm{ClO}_{4}\right)_{2}\left(\mathrm{C}_{41} \mathrm{H}_{38} \mathrm{~N}_{10} \mathrm{O}_{11} \mathrm{Cl}_{2} \mathrm{Cu}_{2}\right): \mathrm{C}, 47.13 ; \mathrm{H}, 3.67 ; \mathrm{N}, 13.40$. Found: $\mathrm{C}, 46.56 ; \mathrm{H}, 3.79 ; \mathrm{N}, 13.21$.

\section{Physical Methods.}

Electronic absorption spectra were recorded on a Shimadzu UV-3101PC spectrophotometer. Elemental analyses were performed by Atlantic Microlabs, Inc. (Norcross, GA). All ${ }^{1} \mathrm{H}$ NMR spectra were recorded on a Bruker ARX- 
400 spectrometer at $400.13 \mathrm{MHz}$. All one-dimensional spectra were recorded with a spectral width between 125 and $83 \mathrm{kHz}$ with a repetition rate of $3 \mathrm{~s}^{-1}$. Chemical shifts (in ppm) are reported with respect to the residual solvent signals at $1.92 \mathrm{ppm}$ for $\mathrm{CH}_{3} \mathrm{CN}$ and 4.7 for $\mathrm{H}_{2} \mathrm{O}$. Spectra were routinely Fourier transformed with an exponential weighting function and a $30 \mathrm{~Hz}$ line broadening. Longitudinal relaxation times $\left(T_{1}\right)$ were measured by the use of an inversion-recovery pulse sequence $\left(180^{\circ}-\tau-90^{\circ}\right)$. Plots of $\ln \left(I_{0}-I_{\tau}\right)$ vs $\tau$ for each signal provided a straight line over all $\tau$ values investigated. Magnitude ${ }^{1} \mathrm{H}$ COSY spectra were obtained at $400.13 \mathrm{MHz}$ on $\mathbf{1 , 3 , 4}$, and 5 in $\mathrm{CD}_{3} \mathrm{CN}$ solutions. These spectra were obtained at various temperatures and acquisition times depending on the signal widths. These spectra were typically obtained with 512 or 1024 blocks of 1024 or 2048 complex points, respectively. An unshifted sine-bell-squared weighting function was applied prior to Fourier transformation followed by baseline correction in both dimensions and symmetrization.

\section{Results and Discussion}

A fundamental and, as yet, largely unexplored issue is the determination of the structural and magnetic properties of dinuclear $\mathrm{Cu}(\mathrm{II})$ centers in essentially arbitrary environments using ${ }^{1} \mathrm{H}$ NMR spectroscopy. Both antiferromagnetically and ferromagnetically coupled dicopper(II) systems have been shown to provide relatively sharp, hyperfine shifted ${ }^{1} \mathrm{H}$ NMR signals. ${ }^{13,15-23}$ We have synthesized a series of well-characterized, magnetically diverse, $\mu$-phenoxo and $\mu$-alkoxo dicopper(II) complexes with either ferromagnetic or antiferromagnetic properties (Figure 1). Having this series has enabled us to explore the effects of magnetic coupling on their ${ }^{1} \mathrm{H}$ NMR spectral properties as well as the use of two-dimensional (COSY) ${ }^{1} \mathrm{H}$ NMR techniques for signal assignment. In addition, the determination of $T_{1}$ values for each observed ${ }^{1} \mathrm{H}$ NMR resonance has allowed us to address the mechanism of relaxation in both ferromagnetically and antiferromagnetically coupled dicopper(II) centers.

\section{Antiferromagnetically Coupled Systems.}

$\left[\mathrm{Cu}_{2}(\mathrm{BPMP})(\mathrm{OH})\right]^{2+}(\mathbf{1})$ is an antiferromagnetically coupled, crystallographically characterized ( $\mu$-phenoxo) $(\mu-$ hydroxo)dicopper(II) complex with a $-2 J$ value of $187 \mathrm{~cm}^{-1}$ (Figure 1). ${ }^{35}$ The magnetic properties of 1 compare well with several related ( $\mu$-phenoxo)( $\mu$-hydroxo)dicopper(II) complexes, all of which exhibit moderate to strong antiferromagnetic coupling between the $\mathrm{Cu}(\mathrm{II})$ centers with $-2 J$ values greater than $100 \mathrm{~cm}^{-1} .^{27,36-38}$ The Evans susceptibility method ${ }^{39,40}$ provides a room temperature magnetic moment $\left(\mu_{\mathrm{eff}} / \mathrm{Cu}\right)$ of $1.27 \mathrm{BM}$ which gives the number of unpaired electrons $(n / \mathrm{Cu})$ as 0.62 . These data indicate that the $\mathrm{Cu}(\mathrm{II})$ ions in $\mathbf{1}$ are moderately antiferromagnetically coupled in acetonitrile solution. Complex 1 exhibits several sharp, isotropically shifted ${ }^{1} \mathrm{H}$ NMR signals in acetonitrile solution at $25^{\circ} \mathrm{C}$ in the 90 to -50 ppm chemical shift range. ${ }^{20}$ Upon increasing the temperature, all of the isotropically shifted signals sharpen and shift toward the diamagnetic region. A new broad signal at $\sim 130 \mathrm{ppm}$ appears as the temperature is increased to $60{ }^{\circ} \mathrm{C}$ (Figure 2A, Table 1). 


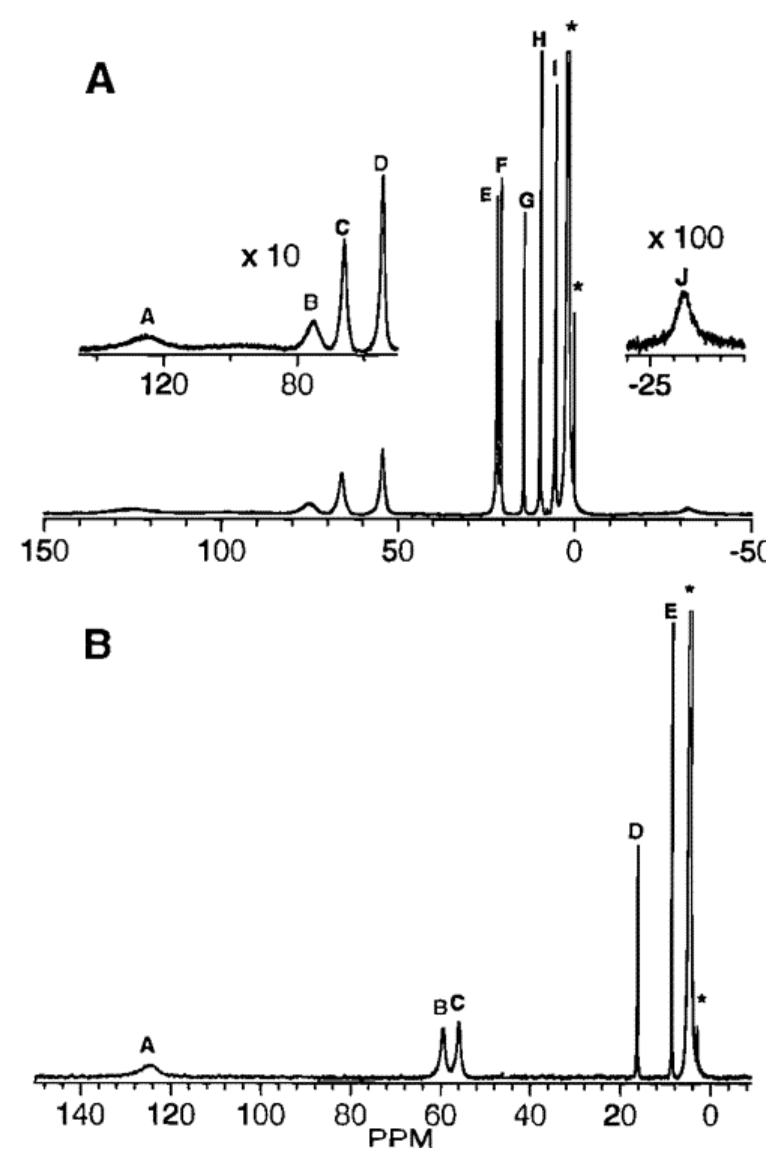

Figure $2{ }^{1} \mathrm{H}$ NMR spectra: (A) spectrum of 1 in $\mathrm{CD}_{3} \mathrm{CN}$ at $60{ }^{\circ} \mathrm{C}$ and (B) spectrum of 2 in $\mathrm{D}_{3} \mathrm{O}$ at $90{ }^{\circ} \mathrm{C}$. Spectra were referenced to the residual protic solvent signals $\left({ }^{*}\right)$ at 1.92 and $4.7 \mathrm{ppm}$ for acetonitrile and water, respectively. 
Table 1. ${ }^{1} \mathrm{H}$ NMR Data for $\left[\mathrm{Cu}_{2}\left(\mathrm{CH}_{3} \mathrm{HXTA}\right)(\mathrm{OH})\right]^{2-}$ in $\mathrm{D}_{2} \mathrm{O}$ Solution at $90^{\circ} \mathrm{C}$ and $\left[\mathrm{Cu}_{2}(\mathrm{BPMP})(\mathrm{OH})\right]^{2+}$ in $\mathrm{CD}_{3} \mathrm{CN}$ Solution at 40 and $60{ }^{\circ} \mathrm{C}$

\begin{tabular}{|c|c|c|c|c|c|c|c|c|c|c|}
\hline & {$\left[\mathrm{Cu}_{2}\left(\mathrm{CH}_{3} \mathrm{HXTA}\right)(\mathrm{OH})\right]^{2-}$} & & & & & {$\left[\mathrm{Cu}_{2}(\mathrm{BPMP})(\mathrm{OH})\right]^{2+}$} & & & & \\
\hline & assignment & $\begin{array}{l}\text { chemical } \\
\text { shift }^{a}\end{array}$ & $\begin{array}{l}\text { relative } \\
\text { area }\end{array}$ & line width ${ }^{b}(\mathrm{~Hz}$ & $\begin{array}{l}T_{1}(\mathrm{~ms} \\
\text { ) }\end{array}$ & assignment & $\begin{array}{l}\text { chemical } \\
\text { shift }^{a}\end{array}$ & $\begin{array}{l}\text { relative } \\
\text { area }\end{array}$ & line width ${ }^{b}(\mathrm{~Hz}$ & $\begin{array}{l}T_{1}(\mathrm{~ms} \\
)\end{array}$ \\
\hline A & $\mathrm{Ph}-\mathrm{CH}_{2}-\mathrm{N}$ & 130 & $\sim 4$ & $\sim 4500$ & 1 & $\mathrm{Ph}-\mathrm{CH}_{2}-\mathrm{N}$ & 130 & $\sim 4$ & $\sim 4000$ & 5 \\
\hline $\mathrm{B}$ & $\mathrm{N}-\mathrm{CH}_{2}-\mathrm{COO}^{-}$ & 61 & $\sim 4$ & $\sim 1500$ & 1 & Py $\alpha-H$ & 77 & $\sim 4$ & 1500 & 3 \\
\hline $\mathrm{C}$ & $\mathrm{N}-\mathrm{CH}_{2}-\mathrm{COO}^{-}$ & 59 & $\sim 4$ & $\sim 1400$ & 1 & $\mathrm{~N}-\mathrm{CH}_{2}-\mathrm{Py}$ & 68 & 4 & 900 & 4 \\
\hline $\mathrm{D}$ & $\mathrm{Ph} \beta-H$ & 16.4 & 2 & 130 & 25 & $\mathrm{~N}-\mathrm{CH}_{2}-\mathrm{Py}$ & 56 & 4 & 475 & 2 \\
\hline $\mathrm{E}$ & $\mathrm{Ph}-\mathrm{CH}_{3}$ & 8.8 & 3 & 70 & 7 & Py $\beta^{\prime}-H$ & 22.4 & 4 & 77 & 24 \\
\hline $\mathrm{F}$ & & & & & & Py $\beta-H$ & 21.3 & 4 & 66 & 24 \\
\hline G & & & & & & $\mathrm{Ph} \beta-H$ & 14.5 & 2 & 40 & 22 \\
\hline $\mathrm{H}$ & & & & & & Py $\mathrm{p}-\mathrm{H}$ & 9.8 & 4 & 32 & 56 \\
\hline 1 & & & & & & $\mathrm{Ph}-\mathrm{CH}_{3}$ & 5.5 & 3 & 23 & 103 \\
\hline $\mathrm{J}$ & & & & & & $\mu-\mathrm{OH}$ & -32 & $\sim 1$ & 850 & 2 \\
\hline
\end{tabular}

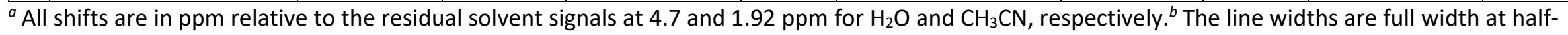
maximum. 
Several of the isotropically shifted ${ }^{1} \mathrm{H}$ NMR signals observed for 1 can be initially assigned by inspection of their peak areas. Signals E (22.4 ppm), F (21.3 ppm), G (14.5 ppm), H (9.8 ppm), and I (5.5 ppm) integrate to 4:4:2:4:3 protons, respectively (Table 1). These data, taken together with the crystallographic results, suggest that signals $\mathrm{E}, \mathrm{F}$, and $\mathrm{H}$ arise from pyridyl protons while signals $\mathrm{G}$ and $\mathrm{I}$ are due to the $m$-phenol and the $p$-methylphenol protons, respectively. Definitive assignment of each of these signals was made by two-dimensional ${ }^{1} \mathrm{H}$ NMR techniques. A magnitude COSY spectrum of 1 was recorded at $25^{\circ} \mathrm{C}$ and clearly shows cross signals between resonances $E$ and $H$ and also between resonances $F$ and $H$ (Figure 3 ). These signals can be unequivocally assigned to the pyridine $\beta-H(E$ or $F), \beta^{\prime}-H(E$ or $F)$, and $\gamma-H(H)$ protons, respectively.

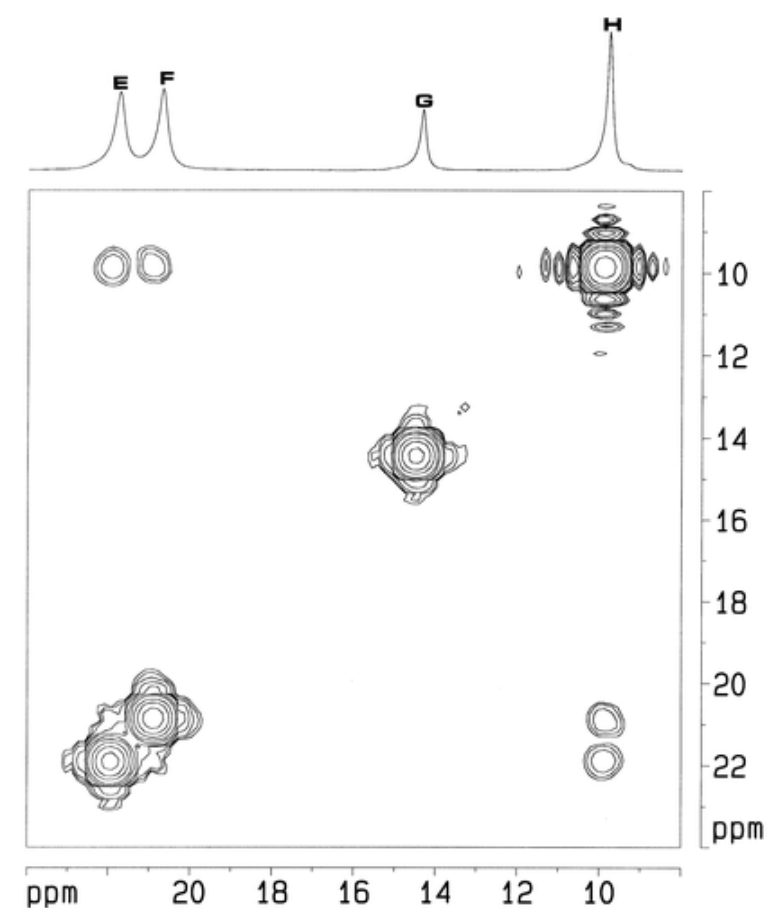

Figure 3 Magnitude ${ }^{1} \mathrm{H}$ COSY spectrum of 1 obtained at $400.13 \mathrm{MHz}$ (Bruker ARX-400) at $60{ }^{\circ} \mathrm{C}$ in $\mathrm{CD}_{3} \mathrm{CN}$ solution. The spectrum was referenced to the residual protic solvent signal at $1.92 \mathrm{ppm}$. This spectrum was obtained with an acquisition time of $6 \mathrm{~ms}$ and 128 data points in the F1 dimension and 256 data points in the F2 dimension. An unshifted sine-bell-squared weighting function and zero-filling to 512 data points were applied prior to Fourier transformation in both dimensions followed by baseline correction in both dimensions and symmetrization.

Assignment of the remaining signals of 1 comes from $T_{1}$ values and comparison of the spectrum of 1 with that of a related complex $\left[\mathrm{Cu}_{2}\left(\mathrm{CH}_{3} \mathrm{HXTA}\right)(\mathrm{OH})\right]^{2-}(2)$ where the methylpyridyl ligands have been replaced by acetate moieties (Figure 1). ${ }^{21}$ The ${ }^{1} \mathrm{H}$ NMR spectrum of $\mathbf{2}$ shows five isotropically shifted signals at $60{ }^{\circ} \mathrm{C}$ in $\mathrm{D}_{2} \mathrm{O}$ solution and $\mathrm{pH} 10$ (Figure 2B). The assignment of each of the observed hyperfine shifted signals for $\mathbf{2}$ has been previously reported (Table 1). ${ }^{21}$ Comparison of the chemical shift, $T_{1}$ values, and relative integrations of signals $\mathrm{B}$ (61 ppm) and C (59 ppm) of complex $\mathbf{2}$ (which were assigned to the diastereotopic methylene- $\mathrm{CH}_{2}$ acetate protons) with signals $C(68 \mathrm{ppm})$ and $\mathrm{D}(56 \mathrm{ppm})$ of 1 are consistent with the assignment of these signals to the diastereotopic methylene- $\mathrm{CH}_{2}$ protons of the pyridylmethyl moiety. Comparison of signal A (130 ppm) of 2 with signal $\mathrm{A}(130 \mathrm{ppm})$ of $\mathbf{1}$ is consistent with this signal resulting from the methylene- $\mathrm{CH}_{2}$ protons of the phenol-methylamine linkage.

Signals B (77 ppm) and J (-32 ppm) are the only remaining unassigned signals in the ${ }^{1} \mathrm{H}$ NMR spectrum of 1 . The only protons in $\mathbf{1}$ not assigned are the pyridine $\alpha-\mathrm{H}$ protons and the $\mu$-hydroxo $\mathrm{OH}$ proton. Signal J can be assigned to the $\mu$-hydroxo $\mathrm{OH}$ proton since the addition of a small amount of $\mathrm{D}_{2} \mathrm{O}$ causes this signal to disappear. ${ }^{19,20}$ The corresponding ${ }^{2} \mathrm{H}$ NMR experiment reveals a resonance at the appropriate chemical shift, 
thus allowing unambiguous assignment of $\mathrm{J}$ as the $\mu$-hydroxo $\mathrm{OH}$ proton. Moreover, the $T_{1}$ value is $\sim 1 \mathrm{~ms}$, which is consistent with the short crystallographically determined $\mathrm{Cu}-\mathrm{H}$ distance (2.54 $\AA$ ). From X-ray diffraction studies on 1 , the $\mathrm{Cu} \mathrm{d}_{z 2}$ orbital, which contains the unpaired electron, is directed along the $\mathrm{Cu}-\mathrm{O} \mu$-hydroxo bond. ${ }^{20}$ Therefore, a spin polarization mechanism would cause the $\mu$-hydroxo proton to be shielded and thus shifted upfield, consistent with its assignment to signal J. Signal B can be assigned to the pyridine $\alpha-H$ protons by default, and this assignment is consistent with $T_{1}$ values, chemical shift, and relative integrations.

$\left[\mathrm{Cu}_{2}(m-\mathrm{XYL})(\mathrm{OH})\right]^{2+}(3)$ contains two strongly coupled $\mathrm{Cu}(\mathrm{II})$ ions with a $-2 J$ value, determined from SQUID susceptibility measurements, of $600 \mathrm{~cm}^{-1}$ (Figure 1). ${ }^{26,27}$ From the Evans susceptibility method, the room temperature magnetic moment $\left(\mu_{\text {eff }} / \mathrm{Cu}\right.$ ) of $\mathbf{3}$ in acetonitrile solution is $0.67 \mathrm{BM}$, which gives the number of unpaired electrons $(n / \mathrm{Cu})$ as 0.33 . These data confirm that the $\mathrm{Cu}(\mathrm{II})$ ions in $\mathbf{3}$ are strongly coupled in acetonitrile solution. Interestingly, the ${ }^{1} \mathrm{H}$ NMR spectrum of 3 at $25{ }^{\circ} \mathrm{C}$ shows 20 isotropically shifted signals in the 50 to -20 ppm chemical shift range (Figure $4 \mathrm{~A}$ ). As the temperature is decreased, all of the observed signals sharpen and shift toward the diamagnetic region following non-Curie law behavior. The temperature dependence of $\mathbf{3}$ is exactly opposite to that observed for $\mathbf{1}$ and $\mathbf{2}$. The non-Curie law behavior of strongly coupled dicopper(II) systems has previously been shown to be a function of the magnitude of $-2 J{ }^{35}$

A

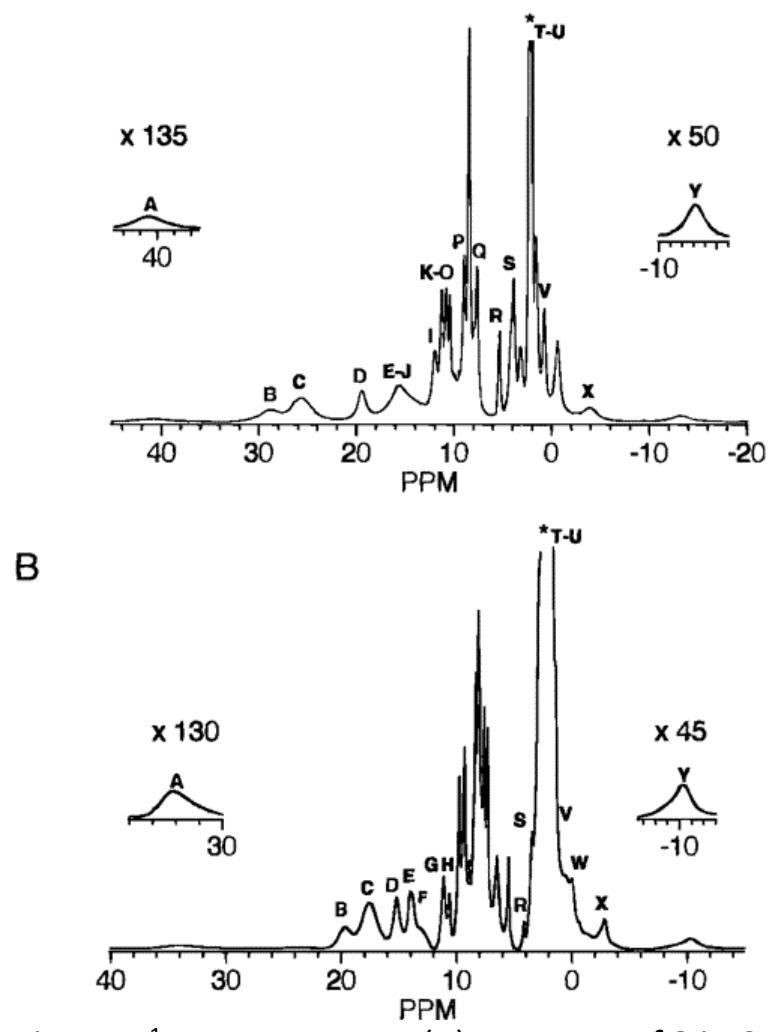

Figure $4{ }^{1} \mathrm{H}$ NMR spectra: (A) spectrum of 3 in $\mathrm{CD}_{3} \mathrm{CN}$ at $25^{\circ} \mathrm{C}$ and (B) spectrum of 3 in $\mathrm{CD}_{3} \mathrm{CN}$ at $-20{ }^{\circ} \mathrm{C}$. Spectra were referenced to the residual protic solvent signals $\left({ }^{*}\right)$ at $1.92 \mathrm{ppm}$ for acetonitrile. The ${ }^{*}$ notes a small impurity as well as the position of the transmitter. Additional peak labels for the $10-0 \mathrm{ppm}$ region appear in Figure 5.

At $-20^{\circ} \mathrm{C}, 25$ sharp hyperfine shifted ${ }^{1} \mathrm{H}$ NMR resonances are observed (Figure 4B). The large number of sharp hyperfine shifted ${ }^{1} \mathrm{H}$ NMR resonances observed for $\mathbf{3}$ suggest asymmetry in the solution structure of $\mathbf{3}$. Inspection of the X-ray crystal structure of $\mathbf{3}$ indicates two distinct sets of pyridine rings. ${ }^{26}$ Two of the pyridine rings occupy axial positions while the remaining two are in equatorial positions of the square pyramidal $\mathrm{Cu}(\mathrm{II})$ 
centers. This difference in environments is reflected in the ${ }^{1} \mathrm{H}$ NMR spectrum in that 40 protons exist in 3 and 25 resonances are observed. If the pyridyl arms were in identical environments in acetonitrile solution, a maximum of 13 resonances would be expected. Tentative assignment of several of the observed hyperfine shifted resonances can be made from inspection of their peak areas and $T_{1}$ values (Table 2); however, definitive assignment of several observed hyperfine shifted resonances can be obtained from a magnitude COSY spectrum.

Table 2. ${ }^{1} \mathrm{H}$ NMR Data for $\left[\mathrm{Cu}_{2}(m-\mathrm{XYL})(\mathrm{OH})\right]^{2+}$ in $\mathrm{CD}_{3} \mathrm{CN}$ Solution at $-20^{\circ} \mathrm{C}$

\begin{tabular}{|c|c|c|c|c|c|}
\hline & assignment & chemical shift $^{a}$ & relative area & line width ${ }^{b}(\mathrm{~Hz})$ & $T_{1}(\mathrm{~ms})$ \\
\hline$A$ & & 34 & 1 & 1200 & 1 \\
\hline B & & 20 & 1 & 650 & 1 \\
\hline $\mathrm{C}$ & & 17.8 & 4 & 600 & 1 \\
\hline $\mathrm{D}$ & & 15.6 & 2 & 260 & 1 \\
\hline$E$ & & 14.3 & 2 & 180 & 14 \\
\hline $\mathrm{F}$ & & 13 & 1 & 500 & 1 \\
\hline G & & 11.6 & 2 & 170 & 4 \\
\hline $\mathrm{H}$ & & 11.1 & 2 & 60 & 39 \\
\hline I & Py $\beta-H$ & 10.3 & 2 & 50 & 50 \\
\hline $\mathrm{J}$ & & 9.9 & & 100 & 22 \\
\hline $\mathrm{K}$ & Py $\beta^{\prime}-H$ & 9.8 & 2 & 70 & 48 \\
\hline $\mathrm{L}$ & $\mathrm{Py} \mathrm{y}-\mathrm{H}$ & 8.9 & 2 & 40 & 110 \\
\hline $\mathrm{M}$ & $\mathrm{Py} \mathrm{p}^{-H}$ & 8.6 & & 40 & 83 \\
\hline $\mathrm{N}$ & Py $\beta-H$ & 8.5 & & 50 & 47 \\
\hline 0 & $\mathrm{Ph} \beta-H$ & 8.1 & 2 & 35 & 59 \\
\hline$P$ & Py $\beta^{\prime}-H$ & 7.8 & 2 & 30 & 66 \\
\hline$Q$ & $\mathrm{Ph} \gamma-H$ & 6.0 & 1 & 30 & 95 \\
\hline$R$ & & 4.0 & 2 & 140 & 5 \\
\hline $\mathrm{S}$ & & 3.4 & 4 & 120 & 8 \\
\hline$T$ & & 2.0 & 2 & 30 & 43 \\
\hline$U$ & & 1.8 & 2 & 50 & 6 \\
\hline $\mathrm{V}$ & & 1.0 & 1 & 350 & 40 \\
\hline$W$ & & 0.5 & 1 & 230 & 4 \\
\hline$x$ & & -2.3 & 1 & 160 & 5 \\
\hline$Y$ & $\mu-\mathrm{OH}$ & -10 & $\sim 1$ & 530 & 1 \\
\hline
\end{tabular}

${ }^{a}$ All shifts are in ppm relative to the residual solvent signal at $1.92 \mathrm{ppm}$ for $\mathrm{CH}_{3} \mathrm{CN} .{ }^{b}$ The line widths are full width at half-maximum.

Clear COSY cross signals are observed between signals $\mathrm{L}(8.9 \mathrm{ppm})$ and $\mathrm{K}(9.8 \mathrm{ppm})$, and between signals $\mathrm{L}$ and I (10.3 ppm) (Figure 5). In addition, clear COSY cross signals are observed between signals $\mathrm{M}(8.6 \mathrm{ppm})$ and $\mathrm{P}(7.8$ $\mathrm{ppm})$, and between signals $\mathrm{M}$ and $\mathrm{N}(8.5 \mathrm{ppm})$. The only sets of three protons in $\mathbf{3}$ that are spin-coupled are those of the pyridine rings. Therefore, signals $L$ and $M$ are assigned to the $\mathrm{\gamma}-\mathrm{H}$ protons of inequivalent pyridine rings. Resonances $\mathrm{K}$ and $\mathrm{I}$ are the corresponding $\beta-\mathrm{H}$ protons of the pyridine rings containing proton L. Likewise, $\mathrm{N}$ and $\mathrm{P}$ are the $\beta-\mathrm{H}$ protons of the pyridine rings containing proton $\mathrm{M}$. Clear COSY cross signals are also observed between signals $O(8.1)$ and $Q(6.0 \mathrm{ppm}$ ) (Figure 5). Signals $O$ and $Q$ can be assigned to the $m$-phenol and $p$-phenol protons, respectively (Table 2 ). This assignment is also consistent with the integrations and $T_{1}$ values of these two resonances. Signal $O$ integrates to two protons while $Q$ integrates to one proton. Moreover, signal $Q$ has a $T_{1}$ value of $95 \mathrm{~ms}$ compared to $59 \mathrm{~ms}$ for $\mathrm{Q}$, consistent with $\mathrm{Q}$ being the $p$-phenol proton which is farther from the paramagnetic dicopper(II) center. 


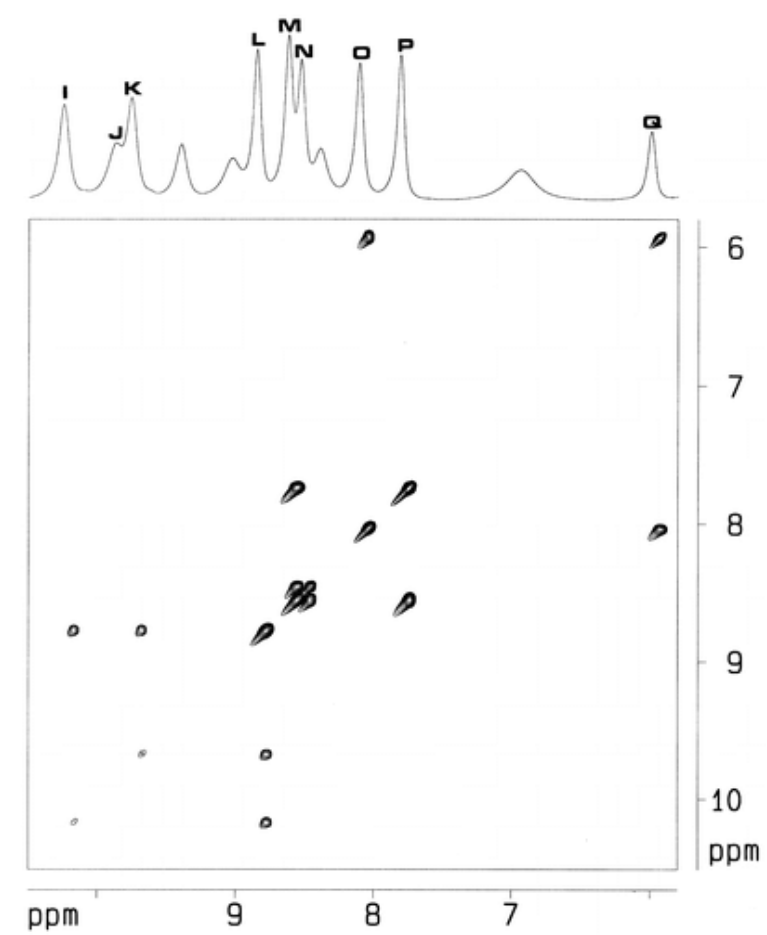

Figure 5 Magnitude ${ }^{1} \mathrm{H}$ COSY spectrum of 3 obtained at $400.13 \mathrm{MHz}$ (Bruker ARX-400) at $-20{ }^{\circ} \mathrm{C}$ in $\mathrm{CD}_{3} \mathrm{CN}$ solution. The spectrum was referenced to the residual protic solvent signal at $1.92 \mathrm{ppm}$. This spectrum was obtained with an acquisition time of $150 \mathrm{~ms}$ and 1536 data points in the F1 dimension and 3072 data points in the F2 dimension. An unshifted-sine-bell squared weighting function and zero-filling to 4096 data points were applied prior to Fourier transformation in both dimensions followed by baseline correction in both dimensions and symmetrization.

The ${ }^{1} \mathrm{H}$ NMR spectrum of 3 at $-20^{\circ} \mathrm{C}$ reveals an upfield shifted signal at $-10 \mathrm{ppm}(\mathrm{Y})$. In $\mathbf{1}$, a similar resonance was assigned to the $\mu$-hydroxo $\mathrm{OH}$ proton by substitution with deuterium. Upon the addition of a drop of $\mathrm{D}_{2} \mathrm{O}$ to an acetonitrile solution of $\mathbf{3}$, signal $\mathrm{Y}$ disappears. ${ }^{2} \mathrm{H}$ NMR experiments show the corresponding resonance at the appropriate chemical shift value, thus substantiating the assignment of $\mathrm{Y}$ to the $\mu$-hydroxo $\mathrm{OH}$ proton. In addition, the $T_{1}$ value for $\mathrm{Y}$ is $\sim 1 \mathrm{~ms}$, consistent with the crystallographically determined short $\mathrm{Cu}-\mathrm{H}$ distance of $2.56 \AA$. The only remaining protons in $\mathbf{3}$ that are unassigned reside on the ethylene and methylene linkages as well as the $\alpha$-pyridine protons. These protons are expected to be closer to the $\mathrm{Cu}(\mathrm{II})$ ions $(<3.5 \AA$ ) causing severe line broadening of the observed ${ }^{1} \mathrm{H}$ NMR resonances. Of the remaining unassigned signals, nearly all have line widths of $150 \mathrm{~Hz}$ or greater. Since the observation of COSY cross signals is a function of $T_{2}$, it is not surprising that no additional cross signals are observed. 


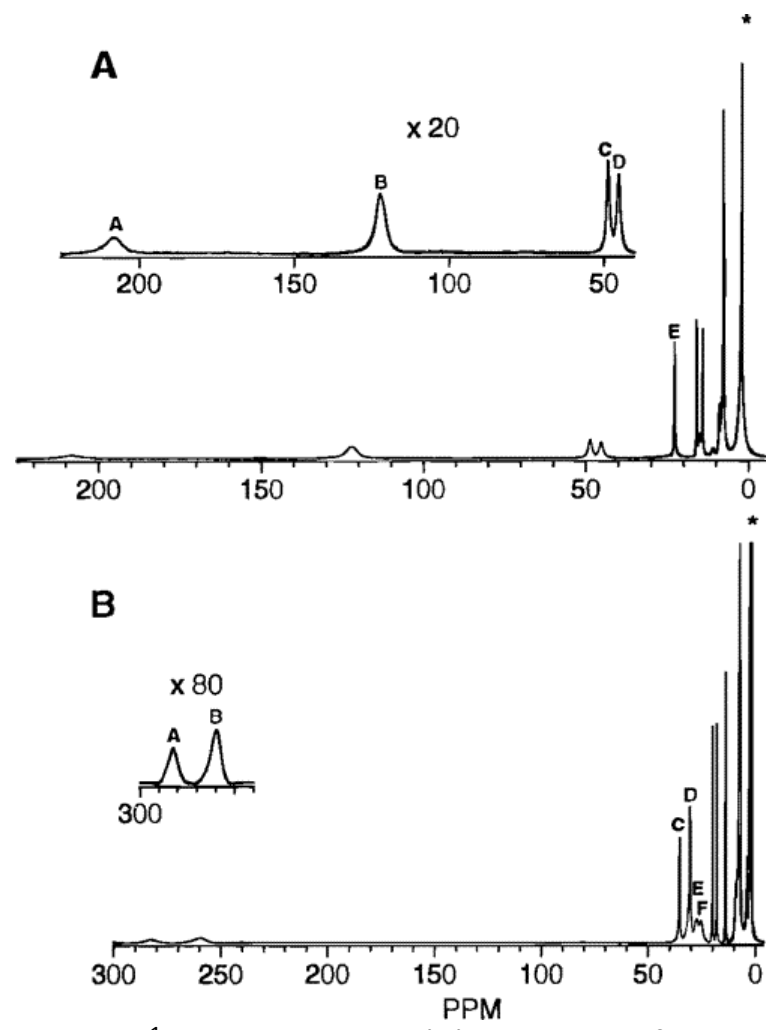

Figure $6{ }^{1} \mathrm{H}$ NMR spectra: (A) spectrum of 4 in $\mathrm{CD}_{3} \mathrm{CN}$ at $55^{\circ} \mathrm{C}$ and (B) spectrum of 5 in $\mathrm{CD}_{3} \mathrm{CN}$ at $-35{ }^{\circ} \mathrm{C}$. Spectra were referenced to the residual protic solvent signals $\left({ }^{*}\right)$ at $1.92 \mathrm{ppm}$ for acetonitrile. The ${ }^{*}$ notes a small impurity as well as the position of the transmitter. Additional peak labels for the 20-0 ppm region appear in Figure 7 or Figure 1S (see supporting information).

Table 3. ${ }^{1} \mathrm{H}$ NMR Data for $\left[\mathrm{Cu}_{2}(\mathrm{TBHP})(\mathrm{OAC})\right]^{2+}$ in $\mathrm{CD}_{3} \mathrm{CN}$ Solution at $60^{\circ} \mathrm{C}$

\begin{tabular}{|l|l|l|l|l|l|}
\hline & assignment & chemical shift $^{a}$ & relative area & line width $^{b}(\mathrm{~Hz})$ & $T_{1}$ (ms) \\
\hline $\mathrm{A}$ & $\mathrm{N}-\mathrm{CH}_{2}-\mathrm{CH}$ & 210 & $\sim 2$ & 2700 & $\sim 1$ \\
\hline $\mathrm{B}$ & $\mathrm{N}-\mathrm{CH}_{2}-\mathrm{Bz}$ & 120 & 4 & 1500 & 1 \\
\hline $\mathrm{C}$ & $\mathrm{N}-\mathrm{CH}_{2}-\mathrm{Bz}$ & 48 & 2 & 540 & 2 \\
\hline $\mathrm{D}$ & $\mathrm{N}-\mathrm{CH}_{2}-\mathrm{Bz}$ & 45 & 2 & 520 & 2 \\
\hline $\mathrm{E}$ & $\mathrm{OOC}-\mathrm{CH}_{3}$ & 22.4 & 3 & 110 & 3 \\
\hline $\mathrm{F}$ & $\mathrm{Bz} \beta-$ or $\alpha^{\prime}-\mathrm{H}$ & 15.7 & 2 & 65 & 45 \\
\hline $\mathrm{G}$ & $\mathrm{N}-\mathrm{H}$ & 15 & 2 & 415 & 2 \\
\hline $\mathrm{H}$ & $\mathrm{Bz} \beta^{\prime}-\mathrm{H}$ & 13.8 & 2 & 80 & 29 \\
\hline $\mathrm{I}$ & $\mathrm{N}-\mathrm{CH}_{2}-\mathrm{CH}$ & 11 & $\sim 2$ & 480 & 2 \\
\hline $\mathrm{J}$ & $\mathrm{Bz} \alpha-H$ & 8.7 & 2 & 215 & 3 \\
\hline $\mathrm{K}$ & $\mathrm{Bz} \alpha-H$ & 8.1 & 2 & 245 & 4 \\
\hline $\mathrm{L}$ & $\mathrm{Bz} \beta-$ and $\alpha^{\prime}-H$ & 7.5 & 4 & 90 & 44 \\
\hline $\mathrm{M}$ & $\mathrm{Bz} \beta-$ or $\alpha^{\prime}-\mathrm{H}$ & 7.3 & 2 & 80 & 42 \\
\hline $\mathrm{N}$ & $\mathrm{Bz} \beta^{\prime}-\mathrm{H}$ & 7.2 & 2 & 100 & 51 \\
\hline
\end{tabular}

${ }^{a}$ All shifts are in ppm relative to the residual solvent signals at $1.92 \mathrm{ppm}$ for $\mathrm{CH}_{3} \mathrm{CN} .{ }^{b}$ The line widths are full width at half-maximum.

Ferromagnetically Coupled Systems.

$\left[\mathrm{Cu}_{2} \text { (TBHP-Et)(OAC) }\right]^{2+}$ is a ferromagnetically coupled, crystallographically characterized $(\mu$-alkoxo) $(\mu-$ acetato)dicopper(II) complex with a $-2 J$ value of $-24 \mathrm{~cm}^{-1} .{ }^{25}$ We have synthesized the $\mathrm{N}$-protonated derivative 
$\left[\mathrm{Cu}_{2}(\mathrm{TBHP})(\mathrm{OAc})\right]^{2+}(4)$ and characterized it by elemental analysis and electronic absorption spectroscopy (Figure 1). ${ }^{25}$ The Evans susceptibility method was used to determine the room temperature magnetic moment of $4\left(\mu_{\text {eff }} / \mathrm{Cu}\right)$ which is $1.79 \mathrm{BM}$, giving the number of unpaired electrons $(n / \mathrm{Cu})$ as $1.05 .{ }^{39,40}$ These data are consistent with the fact that the $\mathrm{Cu}(\mathrm{II})$ ions in $\mathbf{4}$ are weakly ferromagnetically coupled in acetonitrile solution. Complex 4 exhibits 14 relatively sharp, isotropically shifted ${ }^{1} \mathrm{H}$ NMR resonances in acetonitrile solution at $25^{\circ} \mathrm{C}$ in the 300-0 ppm chemical shift range. Upon increasing the temperature, nearly all of the isotropically shifted signals sharpen and shift toward the diamagnetic region following Curie law behavior. The signals between 7 and $9 \mathrm{ppm}$ are clearly resolved at $60^{\circ} \mathrm{C}$ (Figure 6A); thus, all of our NMR studies were performed at this temperature (Table 3$)$. The ${ }^{1} \mathrm{H}$ NMR spectrum of the $\mathrm{N}$-methylated dicopper(II) complex [ $\mathrm{Cu}_{2}(\mathrm{TBHP}-$

$\mathrm{Me}(\mathrm{OAC})]^{2+}$ in acetonitrile solution at $23^{\circ} \mathrm{C}$ was recently reported by Satcher and Balch. ${ }^{22}$ The ${ }^{1} \mathrm{H}$ NMR spectrum of 4 is qualitatively similar to that reported with the exception of the $\mathrm{N}$-methylated methyl protons that resonated at $\sim 5$ and $\sim 3 \mathrm{ppm}$.

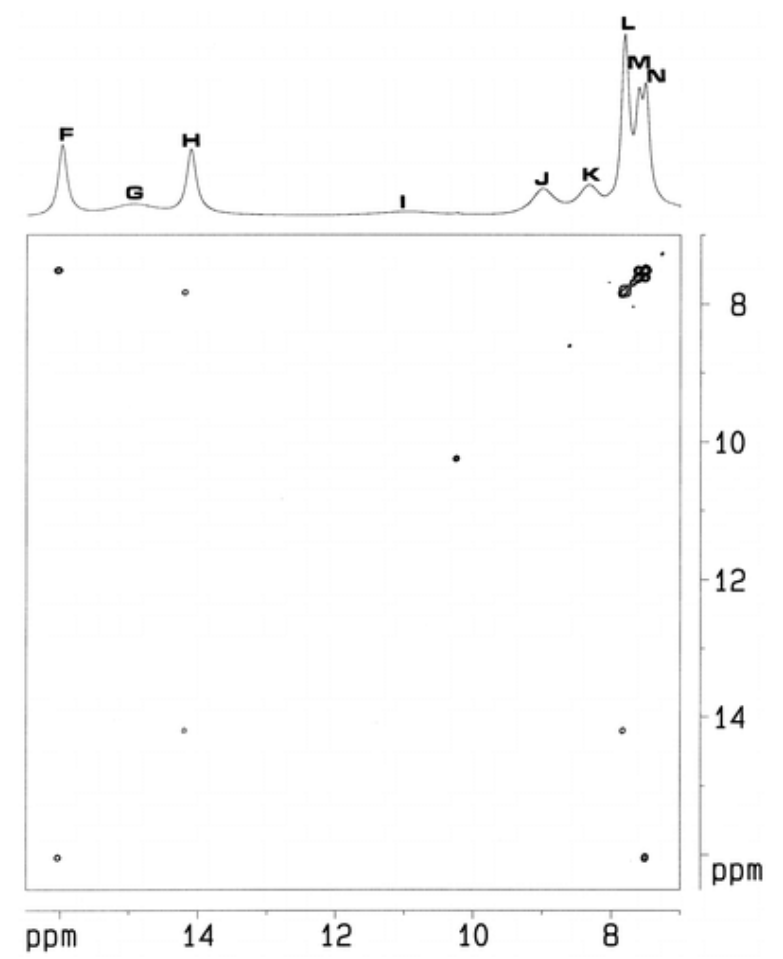

Figure 7 Magnitude ${ }^{1} \mathrm{H}$ COSY spectrum of 4 obtained at $400.13 \mathrm{MHz}$ (Bruker ARX-400) at $55^{\circ} \mathrm{C}$ in $\mathrm{CD}_{3} \mathrm{CN}$ solution. The spectrum was referenced to the residual protic solvent signal at $1.92 \mathrm{ppm}$. This spectrum was obtained with an acquisition time of $125 \mathrm{~ms}$ and 1024 data points in the F1 dimension and 2048 data points in the F2 dimension. An unshifted sine-bell-squared weighting function and zero-filling to 3072 data points were applied prior to Fourier transformation in both dimensions followed by baseline correction in both dimensions and symmetrization. 
Table 4. Average $\mathrm{Cu}-\mathrm{H}$ Distances Determined from X-ray Crystal Structures of 1-4 and the Calculated Cu-H Distances Determined from $T_{1}$ Data for Assigned ${ }^{1} \mathrm{H}$ NMR Resonances

\begin{tabular}{|c|c|c|c|c|c|c|c|c|}
\hline & $\begin{array}{l}{\left[\mathrm{Cu}_{2}\left(\mathrm{CH}_{3} \mathrm{HXTA}\right)(\mathrm{OH})\right.} \\
]^{2-}\end{array}$ & & {$\left[\mathrm{Cu}_{2+}(\mathrm{BPMP})(\mathrm{OH})\right]$} & & {$\left[\mathrm{Cu}_{2}(m-\mathrm{XYL})(\mathrm{OH})\right]^{2+}$} & & {$\left[\mathrm{Cu}_{2+}(\mathrm{TBHP})(\mathrm{OAC})\right]$} & \\
\hline & average ${ }^{a} \mathrm{Cu}-\mathrm{H}(\AA)$ & $\begin{array}{l}\text { calcd }{ }^{b} \mathrm{Cu}-\mathrm{H} \text { ( } \\
\AA \\
\AA\end{array}$ & $\begin{array}{l}\text { average }{ }^{a} \mathrm{Cu}-\mathrm{H}(\AA \AA \\
)\end{array}$ & $\begin{array}{l}\text { calcd }{ }^{b} \mathrm{Cu}-\mathrm{H}( \\
\AA \\
\AA\end{array}$ & average ${ }^{a} \mathrm{Cu}-\mathrm{H}(\AA)$ & $\begin{array}{l}\text { calcd }{ }^{b} \mathrm{Cu}-\mathrm{H}( \\
\AA \\
\AA\end{array}$ & average ${ }^{a} \mathrm{Cu}-\mathrm{H}(\AA)$ & $\begin{array}{l}\text { calcd }{ }^{b} \mathrm{Cu}-\mathrm{H}( \\
\AA \\
\AA\end{array}$ \\
\hline$A$ & 3.46 & 4.2 & 3.42 & 4.4 & & & 3.3 & 3.7 \\
\hline$B$ & 3.73 & 4.2 & 3.16 & 4.1 & & & 3.6 & 3.7 \\
\hline$C$ & 2.98 & 4.2 & 3.68 & 4.3 & & & 3.8 & 4.1 \\
\hline $\mathrm{D}$ & 5.07 & 5.7 & 3.17 & 3.8 & & & 4.1 & 4.1 \\
\hline$E$ & 7.14 & - & 4.89 & 5.7 & & & 4.7 & 4.4 \\
\hline$F$ & & & 5.11 & 5.7 & & & 5.9 & 6.9 \\
\hline $\mathrm{G}$ & & & 5.13 & 5.7 & & & 5.0 & 4.1 \\
\hline $\mathrm{H}$ & & & 5.75 & 6.6 & & & 6.0 & 6.4 \\
\hline 1 & & & 7.31 & - & 5.07 & 5.6 & 3.9 & 4.1 \\
\hline $\mathrm{J}$ & & & 2.54 & 3.8 & & & 3.6 & 4.4 \\
\hline $\mathrm{K}$ & & & & & 4.99 & 4.9 & 3.5 & 4.6 \\
\hline $\mathrm{L}$ & & & & & 5.77 & 6.4 & 6.5 & 6.9 \\
\hline $\mathrm{M}$ & & & & & 5.77 & 5.8 & 6.5 & 6.8 \\
\hline $\mathrm{N}$ & & & & & 5.07 & 5.9 & 7.0 & - \\
\hline 0 & & & & & 5.19 & 6.0 & & \\
\hline $\mathrm{P}$ & & & & & 4.99 & 3.6 & & \\
\hline$Q$ & & & & & 6.47 & - & & \\
\hline$Y$ & & & & & 2.56 & 4.5 & & \\
\hline
\end{tabular}

${ }^{a}$ Crystallographically determined average distances. All $\mathrm{Cu}-\mathrm{H}$ average distances are taken as the arithmetic average of equivalent protons to each $\mathrm{Cu}(\mathrm{II})$ ion. ${ }^{b}$ Distances calculated from $r_{i}=r_{\text {ref }}\left(T_{1 i} / T_{1 \text { ref }}\right)^{1 / 6}$ assuming that $r_{\text {ref }}$ is purely dipolar in nature. 
Satcher and Balch assigned only three of the approximately 15 observed resonances of $\left[\mathrm{Cu}_{2}(\mathrm{TBHP}-\right.$ $\mathrm{Me})(\mathrm{OAc})]^{2+}$ by deuteration of the TBHP ligand. ${ }^{22}$ Their results indicate that signals A (210 ppm) and I (11 ppm) are due to the diastereotopic methylene protons of the isopropyl alcohol linkage. The signal observed at 26.5 ppm (22.5 ppm for 4; E) was assigned to the acetate protons which was confirmed by deuteration experiments. Specific assignments of the remaining signals were not reported. We confirmed the assignment of signal $\mathrm{E}$ as the acetate protons by substitution of the acetate bridge with benzoate $\left[\mathrm{Cu}_{2}(\mathrm{TBHP})(\mathrm{OBz})\right]\left(\mathrm{ClO}_{4}\right)_{2}(5)$. The signal at $22.5 \mathrm{ppm}$ disappears and is replaced by three new resonances at 27.5, 14.0 and 7.2 ppm (Figure 6B). The remainder of the ${ }^{1} \mathrm{H}$ NMR spectrum of 5 is qualitatively similar to that of 4 . A magnitude COSY spectrum of 5 reveals a clear cross signal between the two resonances at 14.0 and $7.2 \mathrm{ppm}$ (see supporting information). These signals are assigned to the $m-\mathrm{H}$ and $p-\mathrm{H}$ protons of the benzoate ring moiety, respectively. This assignment is also consistent with the integrations and $T_{1}$ values determined for these resonances (see supporting information).

A magnitude COSY spectrum of 4 , obtained at $60^{\circ} \mathrm{C}$ in acetonitrile solution, shows clear cross signals between several resonances (Figure 7). Clear COSY cross signals are observed between signals N (7.2 ppm) and M (7.3 ppm), and signals $N$ and $F(15.7 \mathrm{ppm}$ ) (Figure 7). These signals can be unequivocally assigned to a set of benzimidazole ring $\alpha^{\prime}-H$ (F or $\left.M\right), \beta-H(F$ or $M)$, and $\beta^{\prime}-H(N)$ protons, respectively (Figure 1$)$. A second clear COSY cross signal is observed between signals $L(7.5 \mathrm{ppm})$ and $\mathrm{H}(13.8 \mathrm{ppm})$. Inspection of the integrations for these two resonances indicates that $L$ has twice the area of $H$. These data suggest that $H$ is a benzimidazole $\beta^{\prime}-H$ proton while $L$ is the benzimidazole $\alpha^{\prime}$ - and $\beta-H$ protons. Similar to 3,4 has benzimidazole rings in different environments in acetonitrile solution. Examination of the X-ray crystallographic data for the $\mathrm{N}$-ethylated derivative of 4 reveals that both $\mathrm{Cu}(\mathrm{II})$ ions reside in trigonal bipyramidal environments with inequivalent benzimidazole groups. ${ }^{25}$ This observation is consistent with the ${ }^{1} \mathrm{H}$ spectrum of 4 and verifies the solid state structure is maintained in solution.

The remaining observed ${ }^{1} \mathrm{H}$ NMR resonances for 4 that are unassigned are signals B (120 ppm), C (48 ppm) D (45 ppm), $\mathrm{G}(15 \mathrm{ppm}), \mathrm{J}(8.7)$, and $\mathrm{K}$ (8.1) (Table 3). The observation of the methine proton is unlikely due to its close proximity $(<2.5 \AA)$ to the paramagnetic $\mathrm{Cu}(\mathrm{II})$ ions. Therefore, only the $\mathrm{N}-\mathrm{H}$ and $\alpha-\mathrm{H}$ benzimidazole protons and the methylene- $\mathrm{CH}_{2}$ protons of the benzimidazolemethyl groups remain unaccounted for. Signal $\mathrm{G}$ is assigned to the benzimidazole $\mathrm{N}-\mathrm{H}$ protons since the addition of a drop of $\mathrm{D}_{2} \mathrm{O}$ causes it to disappear in $24 \mathrm{~h}$. Similarly, the broad signal observed at $35 \mathrm{ppm}$ for 5 can be exchanged for deuterium upon the addition of $\mathrm{D}_{2} \mathrm{O}$. ${ }^{2} \mathrm{H} N M R$ experiments confirm these assignments. Since many dinuclear enzyme active sites contain histidine residues, the chemical shift of the $\mathrm{N}-\mathrm{H}$ exchangeable protons in $\mathbf{4}$ and $\mathbf{5}$ provide essential chemical shift information for these types of protons. On the basis of a series of model complexes, Maekawa et al. ${ }^{17}$ and, more recently, Satcher and Balch ${ }^{22}$ have correlated isotropic shift with the spin-coupling constant $-2 J$. Both of these studies showed that the larger the isotropic shift the larger $\mu_{\text {eff }} / \mathrm{Cu}$ and, consequently, smaller $-2 J$ values.

Since $\mathbf{4}$ and $\mathbf{5}$ are both ferromagnetically coupled, the chemical shifts of the $\mathrm{N}-\mathrm{H}$ protons may represent the upper limit for these types of protons.

Assignment of the remaining five signals is difficult due to their large line widths and identical integrations of two protons each; however, by default the only unassigned protons in $\mathbf{4}$ are the $\alpha-\mathrm{H}$ benzimidazole protons and the methylene- $\mathrm{CH}_{2}$ protons of the benzimidazolemethyl moieties (Table 3). It seems likely that the farthest downfield shifted signals $\mathrm{B}, \mathrm{C}$, and $\mathrm{D}$ are due to the diastereotopic methylene- $\mathrm{CH}_{2}$ protons of the benzimidazolemethyl groups similar to signals $\mathrm{A}$ and $\mathrm{I}$, previously assigned to the diastereotopic methylene protons of the isopropyl alcohol linkage. Therefore, signals $\mathrm{J}$ and $\mathrm{K}$ can be tentatively assigned to the $\alpha-\mathrm{H}$ benzimidazole protons. Assuming a predominant contact shift mechanism, the chemical shift of the benzimidazole $\alpha-\mathrm{H}$ protons would be expected to be less than those of the methylene- $\mathrm{CH}_{2}$ protons of the benzimidazolemethyl moieties. This is also consistent with our assignments. 


\section{Relaxation Properties.}

The assignment of the ${ }^{1} \mathrm{H}$ NMR spectra of these complexes combined with X-ray crystallographic results and $T_{1}$ values allows the dominant proton relaxation pathway to be determined. Assuming a paramagnetic dipolar relaxation mechanism for coupled dinuclear $\mathrm{Cu}(\mathrm{II})$ complexes, the $\mathrm{Cu}-\mathrm{H}$ distance $(r)$ should be proportional to $T_{1}{ }^{1 / 6}$ (Table 4). ${ }^{4}$ Using the equation $r_{i}=r_{\text {ref }}\left(T_{1 i} / T_{1 \text { ref }}\right)^{1 / 6}$ where $r_{i}$ is the $\mathrm{Cu}-\mathrm{H}_{i}$ distance, $r_{\text {ref }}$ is the $\mathrm{Cu}-\mathrm{H}_{\text {ref }}$ distance, $T_{1 i}$ is the relaxation time of proton $i$, and $T_{1 \text { ref }}$ is the relaxation time of a reference proton, distances of each proton from the $\mathrm{Cu}(\mathrm{II})$ center can be estimated. If $r_{\text {ref }}$ is taken as the arithmetic average of equivalent protons to each $\mathrm{Cu}(\mathrm{II})$ ion for the proton with the greatest distance from the copper ions, the remaining distances of all of the protons in the complexes can be calculated (Table 4). All of the calculated average $\mathrm{Cu}-\mathrm{H}$ distances from definitively assigned protons of 1-4 are within $\mathrm{ca}$. $20 \%$ of the average $\mathrm{Cu}-\mathrm{H}$ distances derived from X-ray crystallographic data (Table 4). These data indicate, contrary to the suggestion by Satcher and Balch, ${ }^{22}$ that a paramagnetic dipolar relaxation mechanism is the dominant relaxation pathway in spin-coupled dicopper(II) complexes.

\section{Conclusions}

Isotropically shifted ${ }^{1} \mathrm{H}$ NMR signals can be easily observed for both antiferromagnetically and ferromagnetically coupled dicopper(II) complexes, and both one- and two-dimensional ${ }^{1} \mathrm{H}$ NMR techniques can be performed. The exchangeable $\mathrm{N}-\mathrm{H}$ and $\mu$-hydroxo $\mathrm{O}-\mathrm{H}$ protons of $\mathbf{1 , 3}, \mathbf{4}$, and 5 provide important chemical shift and $T_{1}$ information for similar protons residing in metalloprotein active sites. Two-dimensional COSY experiments provide clear cross signals for resonances $<200 \mathrm{~Hz}$ wide and establish spin-spin connectivities. Our studies show that COSY data facilitate the assignment of hyperfine shifted ${ }^{1} \mathrm{H}$ NMR signals in dicopper(II) complexes and that these studies verify that the solid state structure exists in solution for each system studied. Furthermore, the relaxation process for dicopper(II) systems is primarily regulated by a dipolar mechanism. This allows $T_{1}$ values to be used as a measure of the distance any given proton resides from a dicopper(II) center. These data, taken collectively, suggest that ${ }^{1} \mathrm{H}$ NMR spectroscopy is an excellent structural and magnetic probe of dicopper(II) complexes in solution. The application of both one- and two-dimensional ${ }^{1} \mathrm{H}$ NMR methods to dicopper(II) metalloprotein active sites is currently under investigation in our laboratory.

\section{Supporting Information Available}

A table of ${ }^{1} \mathrm{H}$ NMR data for $\left[\mathrm{Cu}_{2}(\mathrm{TBHP})(\mathrm{OBz})\right]^{2+}(\mathbf{5})$ and a magnitude COSY spectrum of 5 in acetonitrile solution at $-35^{\circ} \mathrm{C}$ (3 pages). Ordering information is given on any current masthead page.

\section{Terms \& Conditions}

Electronic Supporting Information files are available without a subscription to ACS Web Editions. The American Chemical Society holds a copyright ownership interest in any copyrightable Supporting Information. Files available from the ACS website may be downloaded for personal use only. Users are not otherwise permitted to reproduce, republish, redistribute, or sell any Supporting Information from the ACS website, either in whole or in part, in either machine-readable form or any other form without permission from the American Chemical Society. For permission to reproduce, republish and redistribute this material, requesters must process their own requests via the RightsLink permission system. Information about how to use the RightsLink permission system can be found at http://pubs.acs.org/page/copyright/permissions.html.

\section{Acknowledgment}

This work was supported by the National Science Foundation (CHE-9422098) and the Petroleum Research Fund (ACS-PRF 28635-G). The Bruker ARX-400 NMR spectrometer was purchased with funds provided by the National 
Science Foundation (CHE-9311730) and Utah State University. The authors thank Dr. Kenneth Karlin for graciously supplying the $\left[\mathrm{Cu}_{2}(m-\mathrm{XYL})(\mathrm{OH})\right]\left(\mathrm{PF}_{6}\right)_{2}$ complex.

\section{References}

1 La Mar, G. N.; Eaton, G. R.; Holm, R. H.; Walker, F. A. J. Am. Chem. Soc. 1972, 95, 63-75.

2 Bertini, I.; Luchinat, C. NMR of Paramagnetic Molecules in Biological Systems; Benjamin \& Cummings: Menlo Park, CA, 1986.

3 Bertini, I.; Turano, P.; Vila, A. J. Chem. Rev. 1993, 93, 2833-2932.

4 La Mar, G. N.; de Ropp, J. S. NMR Methodology for Paramagnetic Proteins; Plenum Press: New York, 1993; Vol. 12, pp 1-78.

5 Cheng, H.; Markely, J. L. Annu. Rev. Biophys. Biomol. Struct. 1995, 24, 209-237.

6 Sorrell, T. N. Tetrahedron 1989, 45, 3-68.

7 Solomon, E. I.; Lowery, M. D.; Lacroix, L. B.; Root, D. E. Methods Enzymol. 1993, 226, 1-33.

8 Solomon, E. I.; Baldwin, M. J.; Lowery, M. D. Chem. Rev. 1992, 92, 521-542.

9 Solomon, E. I.; Tuczek, F.; Root, D. E.; Brown, C. A. Chem. Rev. 1994, 94, 827-856.

10 Karlin, K. D.; Tyeklar, Z. Bioinorganic Chemistry of Copper; Chapman \& Hill: New York, NY, 1993.

11 Karlin, K. D. Science 1993, 261, 701-708.

12 Kitajima, N.; Moro-oka, Y. Chem. Rev. 1994, 94, 737-757.

13 Byers, W.; Williams, R. J. P. J. Chem. Soc., Dalton Trans. 1972, 555-560.

14 Drago, R. S. Physical Methods for Chemists, 2nd ed.; Saunders: Orlando, FL, 1992.

15 Zelonka, R. A.; Baird, M. C. Inorg. Chem. 1972, 11, 134-137.

16 Wang, S.; Pang, Z.; Zheng, J.-C.; Wagner, M. J. Inorg. Chem. 1993, 32, 5975-5980.

17 Maekawa, M.; Kitagawa, S.; Munakata, M.; Masuda, H. Inorg. Chem. 1989, 28, 1904-1909.

18 Dei, A.; Gatteschi, D.; Piergentili, E. Inorg. Chem. 1979, 18, 89-93.

19 Kitajima, N.; Fujisawa, K.; Fujimoto, C.; Moro-oka, Y.; Hashimoto, S.; Kitagawa, T.; Toriumi, K.; Tatsumi, K.; Nakamura, A. J. Am. Chem. Soc. 1992, 114, 1277-1291.

20 Holz, R. C.; Brink, J. M. Inorg. Chem. 1994, 33, 4609-4610.

21 Holz, R. C.; Brink, J. M.; Gobena, F. T.; O'Connor, C. J. Inorg. Chem. 1994, 33, 6086-6092.

22 Satcher, J. H.; Balch, A. L. Inorg. Chem. 1995, 34, 3371-3373.

23 Satcher, J. H.; Droege, M. W.; Weakley, T. J. R.; Taylor, R. T. Inorg. Chem. 1995, 33, 3317-3328.

24 Abbreviations: $\mathrm{CH}_{3} \mathrm{HXTA}=N, N$ '-(2-hydroxy-5-methyl-1,3-xylylene)bis( $N$-carboxymethylglycine); BPMP = 2,6bis[[bis(2-pyridylmethyl)amino]methyl]-4-methylphenol; $m$-XYL $=2,6$-bis[[bis(2pyridylethyl)amino]methyl]phenol; TBHP = N,N,N',N'-tetrakis[(2-benzimidazolyl)methyl]-2-hydroxy-1,3diaminopropane.

25 McKee, V.; Zvagulis, M.; Dagdigian, J. V.; Patch, M. G.; Reed, C. A. J. Am. Chem. Soc. 1984, 106, 4765-4772.

26 Karlin, K. D.; Hayes, J. C.; Gultneh, Y.; Cruse, R. W.; McKown, J. W.; Hutchinson, J. P.; Zubieta, J. J. Am. Chem. Soc. 1984, 106, 2121-2128.

27 Karlin, K. D.; Farooq, A.; Hayes, J. C.; Brett, I. C.; Rowe, T. M.; Sinn, E.; Zubieta, J. Inorg. Chem. 1987, 26, 1271-1280.

28 Maloney, J. J.; Glogowski, M.; Rohrbach, D. F.; Urbach, F. L. Inorg. Chim. Acta 1987, 127, L33-L35.

29 Suzuki, M.; Kanatomi, H.; Murase, I. Chem. Lett. 1981, 1745-1748.

30 Suzuki, M.; Kanatomi, H.; Demura, Y.; Murase, I. Bull. Chem. Soc. Jpn. 1984, 57, 1003-1007.

31 Borovik, A. S.; Papaefthymiou, V.; Taylor, L. F.; Anderson, O. P.; Que, L., Jr. J. Am. Chem. Soc. 1989, 111, 6183-6195.

32 Schwarzenbach, G.; Anderegg, G.; Sallmann, R. Helv. Chim. Acta 1952, 35, 1785-1792.

33 Murch, B. P.; Bradley, F. C.; Boyle, P. D.; Papaefthymiou, V.; Que, L., Jr. J. Am. Chem. Soc. 1987, 109, 7993-8003.

34 Berends, H. P.; Stephan, D. W. Inorg. Chim. Acta 1985, 99, L53-L56.

35 Holz, R. C.; Brink, J. M.; Rose, R. A. J. Magn. Reson. 1995, 119, 125-128. 
36 Murry, K. S. In Biological and Inorganic Chemistry of Copper; Karlin, K. D., Zubieta, J., Eds.; Adenine: Guilderland, NY, 1986; Vol. II.

37 Sorrell, T. N.; Jameson, D. L.; O'Connor, C. J. Inorg. Chem. 1984, 23, 190-195.

38 Oberhausen, K. J.; Richardson, J. F.; Buchanan, R. M.; McCusker, J. K.; Hendrickson, D. N.; Latour, J.-M. Inorg. Chem. 1991, 30, 1357-1365.

39 Evans, D. F. J. Chem. Soc. 1959, 2003-2005.

40 Phillips, W. D.; Poe, M. Methods Enzymol. 1972, 24, 304-317. 